\title{
Stroke rehabilitation
}

\section{$A$ call to action in Saudi Arabia}

Saad M. Bindawas, PT, PhD, Vishal S. Vennu, $B S c, M S c$.

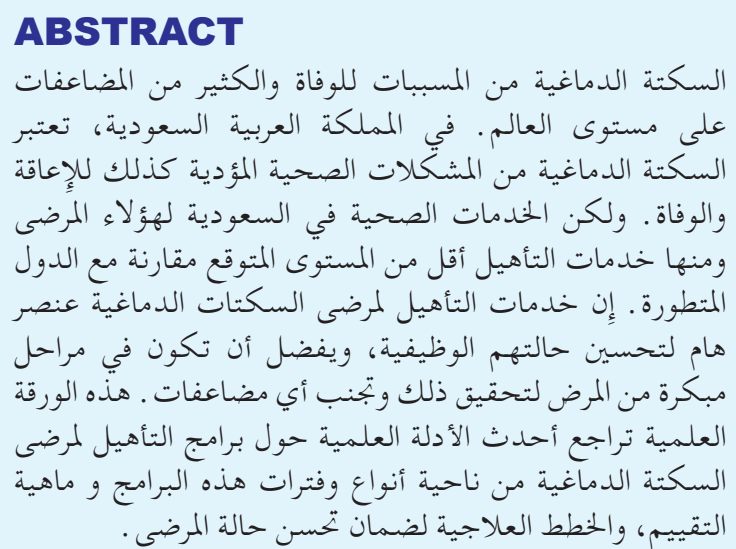

Stroke is a major cause of death and other complications worldwide. In Saudi Arabia, stroke has become an emerging health issue leading to disability and death. However, stroke care including rehabilitation services, in Saudi Arabia lags behind developed countries. Stroke rehabilitation is an essential recovery option after stroke and should start as early as possible to avoid potential complications. The growing evidence on stroke rehabilitation effectiveness in different health care settings and outcome measures used widely are reviewed in this call to action paper.

Neurosciences 2016; Vol. 21 (4): 297-305 doi: 10.17712/nsj.2016.4.20160075

From the Department of Rehabilitation Sciences, College of Applied Medical Sciences, King Saud University, Riyadh, Kingdom of Saudi Arabia

Address correspondence and reprint request to: Dr. Saad M. Bindawas, Associate Professor, Department of Rehabilitation, College of Applied Medical Sciences, King Saud University, PO Box 10219, Riyadh, Saudi Arabia.E-mail: sbindawas@ksu.edu.sa

$\mathrm{T}$ The Kingdom of Saudi Arabia (KSA) is the largest nation in the Arabian Peninsula, stretching over a zone of 2,150,000 square kilometers and boasting a population of more than 28 million. ${ }^{1}$ Stroke is a quickly developing issue, and an imperative reason for disease and death in Saudi Arabia. It has been well documented that stroke is a major cause of death and functional impairment worldwide. ${ }^{2}$ Thus, stroke stands out among the most basic social and financial medical issues in the Kingdom. ${ }^{1}$ The type of stroke in Saudi Arabia is comparable from that reported in western countries, with an inconsistency in the low recurrence of subarachnoid discharge (SAH). ${ }^{1}$ The most important risk factors for stroke in Saudi Arabia are similar to findings in other studies, such as hypertension, diabetes mellitus, heart disease, and smoking. ${ }^{1}$ From the epidemiological perspective, the first reported stroke incidence rate was 29.8 among 100000 Saudi citizen annually. ${ }^{1}$ Saudi Arabia territorial reports demonstrate that stroke is one of the main reasons for morbidity and mortality in the Gizan region, an extensive provincial territory as which has lower stroke occurrence than the reported rates in urban areas. ${ }^{3}$ For health care services for patients with stroke in Saudi Arabia, a recent study found that stroke care on the national level falls behind developed countries. ${ }^{4}$ For example, this study found that out of 350 hospitals, only 2 have a specialized stroke team. The stroke rehabilitation program remains an essential element of recovery after stroke, and should be started as early as possible to avoid potential complications and death. Thus, in this call to action paper, we sought to review the recent literature on stroke rehabilitation effectiveness in different health care settings and the outcome measures that are commonly used in these settings by using the International Classification of Functioning, Disability and Health (ICF) classification of health and health-related domains. ${ }^{5}$

Stroke rehabilitation. As indicated by the ICF model developed by the World Health Organization

Disclosure. The authors have no conflict of interests, and the work was not supported or funded by any drug companies. 
(WHO) in 2001, stroke rehabilitation can be described as a health procedure that "aims to facilitate people with health state experiencing or likely to experience disability to attain optimal functioning in interaction with the environment". ${ }^{5}$ Generally, it is an umbrella for several services to help patients with stroke in improving their physical, psychosocial, and vocational potential, with consideration of the physiologic and environmental limitations. However, various advances have recently been made in the prevention, treatment, and rehabilitation of stroke worldwide. These advances have elicited a significant decrease in the populationbased death rate over the past decade. ${ }^{6}$ Generally, stroke rehabilitation programs remain the essential recommended treatment option for post-stroke functional limitations and disability. ${ }^{7}$

The components of stroke rehabilitation. The primary goals of stroke rehabilitation are to regain independence and improve quality of life by minimizing the limitations of activities of daily living (ADL). ${ }^{8}$ Structured stroke care should consider the early timing of rehabilitation, a qualified rehabilitation team, and duration of rehabilitation, which are important elements that have been distinguished as advancing better general outcomes for patients with stroke. ${ }^{9}$ Evidence from systematic reviews support that organized stroke rehabilitation units, and more prominent intensities of rehabilitation are associated with enhanced improved functional outcomes compared with mixed rehabilitation units, general units, and mobile stroke units. ${ }^{10}$ This suggests that neurological rehabilitation alone does not represent the level of useful changes observed in stroke rehabilitation. ${ }^{9}$ Rehabilitation services regardless of the setting are found to be associated with better functional outcomes. ${ }^{10}$ Examples for these settings where rehabilitation services are provided are stroke wards, ambulatory settings, and others, as shown in Figure 1. There is strong evidence supporting the beneficial effects of early admission to stroke rehabilitation units within 24-48 hours after stroke, to enhance functional outcomes. ${ }^{6}$ However, screening for potential admission to stroke rehabilitation units should be performed when the patient's health state is stable. ${ }^{11}$ The clinician performing the assessment should be specialized in stroke rehabilitation or have extensive experience in neurorehabilitation; as the patient's type and condition severity and classification are vital determinants of disabilities and functional abilities, along with capacity to learn and physical action continuance. $^{11}$ Stroke rehabilitation services consist of a team of professionals' that help with the patient's physical needs, and focus on cognitive, emotional, and vocational skills. ${ }^{12}$ Yet, evidence has shown that stroke rehabilitation professionals cooperating in groups are more effective in enhancing functional recovery and quality of life compared with a single specialty (intra discipline). ${ }^{13}$ The stroke professional team members, and their responsibilities are summarized in Table 1. In terms of the duration, there is no agreement on the ideal time needed to complete the rehabilitation program for patients with stroke. Stroke rehabilitation programs change extensively between settings and units. According to the American Congress of Rehabilitation Medicine, duration is defined as "period of time during which a solitary session is directed". ${ }^{14,15}$ Also, the duration of each stroke rehabilitation session varies depending on several factors such as the recovery, severity, related complications, and responsiveness to therapy. ${ }^{15}$ Although some stroke survivors recover quickly, most need some form of stroke rehabilitation for a longer time, conceivably months or years.

The effectiveness of stroke rehabilitation. In this section, we aim to briefly summarize recent studies

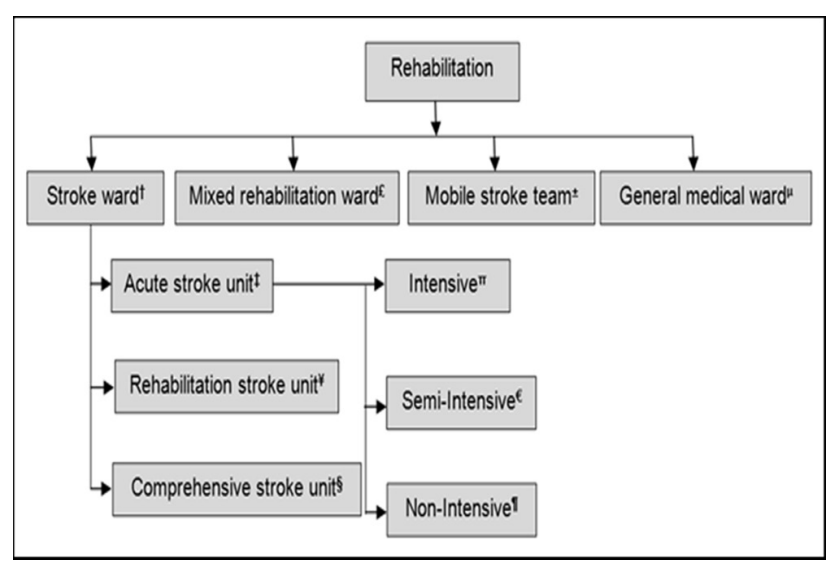

Figure 1 - Elements of a stroke unit associated with improved outcome. ${ }^{\dagger}$ A multidisciplinary team including a specialist nursing staff. \# Stroke patients are assessed in the acute care hospital by a physical therapist or rehabilitation physician who decides the level of mobility impairment and the capacity to endure treatment. Patients are discharged early within 7 days. ${ }^{\pi}$ Model of consideration with constant checking, high medical attendant staff, and life support. ${ }^{\epsilon}$ Model of consideration with constant checking, high medical attendant staff, yet no life support facilities. "Model with no high medical attendant staff or life support facilities. ${ }^{*} \mathrm{~A}$ wide scope of therapeutic and rehabilitative services and settings that give consideration to patients admitted after intense administration in a hospital setting. Patients are accepted after a period of usually of 5 to 7 days or more. ${ }^{~}$ Rehabilitation offered for at least several weeks if necessary. ${ }^{\mathrm{E}} \mathrm{A}$ multidisciplinary group gives a non-specific rehabilitation service, not only watching over stroke patients. ${ }^{ \pm} \mathrm{A}$ multidisciplinary group (barring nursing staff) gives care in an assortment of settings. ${ }^{\circ}$ An intense medicinal or neurology ward without routine multidisciplinary information. 
Table 1 - Stroke rehabilitation team members and their responsibilities.

\begin{tabular}{|c|c|}
\hline Member & Responsibility \\
\hline Patient and family & $\begin{array}{l}\text { Characterizes objectives, assumes control over own rehabilitation program and long-term disability } \\
\text { administration }\end{array}$ \\
\hline Rehabilitation nurse & $\begin{array}{l}\text { Creates a restorative environment, case administration, family instruction, skin and bowel/bladder } \\
\text { care }\end{array}$ \\
\hline Rehabilitation social worker & $\begin{array}{l}\text { Appraisal and administration of family and community assets, discharge arrangements, case } \\
\text { administration }\end{array}$ \\
\hline Physician & $\begin{array}{l}\text { Therapeutic administration of inability, oversees comorbid conditions; included less outside of } \\
\text { serious rehabilitation settings }\end{array}$ \\
\hline Occupational therapist & $\begin{array}{l}\text { Appraisal and treatment of self-consideration aptitudes; upper extremity disability, splints, and } \\
\text { assistive devices }\end{array}$ \\
\hline Physical therapist & $\begin{array}{l}\text { Appraisal and treatment of mobility issues; quality, adaptability, balance, continuance, } \\
\text { coordination, help with mobility }\end{array}$ \\
\hline Orthotics/prosthetics & Suggests, plans, manufactures, and gains individualized equipment \\
\hline Speech and language pathologist & Appraisal and administration of communication disorders, swallowing \\
\hline Psychologist & $\begin{array}{l}\text { Appraisal and administration of cognitive, behavioral, and effective status; connects with the } \\
\text { perceptual-motor and language status }\end{array}$ \\
\hline Dietetics and nutrition & $\begin{array}{l}\text { Appraisal and administration of the dietary state, extraordinary eating regimens, enteral and } \\
\text { parental feeding }\end{array}$ \\
\hline Recreation therapist & $\begin{array}{l}\text { Appraisal and administration of leisure preferences, adoptions, and integration into the therapeutic } \\
\text { plan }\end{array}$ \\
\hline Optometrist & Appraisal and administration of low vision weaknesses and disability \\
\hline
\end{tabular}

on the effectiveness of stroke rehabilitation programs in different settings. Effective stroke rehabilitation programs are defined by an interdisciplinary specialist team, working cohesively and closely providing an extensive rehabilitation program to every patient. ${ }^{16}$ These programs alter regarding the types of therapy offered in addition to their intensity and length of time. In general, successful stroke rehabilitation relies on: physical elements (including the severity of stroke in terms of both cognitive and physical impacts); emotional causes (such as motivation and mood, and ability to stick with rehabilitation activities outside of therapy sessions); social aspects (for example, the support of family); and curative factors (such as an early start to rehabilitation and the skills of the stroke rehabilitation team). ${ }^{12}$ Results from most of the recently published randomized controlled trials (RCTs) provide strong evidence that stroke rehabilitation at the acute stroke stage, ${ }^{17}$ sub-acute stroke stage, ${ }^{18}$ and chronic stroke stage ${ }^{19}$ decreased death and disability. In a recent RCT, ${ }^{9}$ stroke care combined with comprehensive rehabilitation and early supported discharge was associated with enhanced survival rate and functional outcome, and a reduced requirement for institutionalization, and length of hospital stay. ' The Stroke Unit Trialists Collaboration's (SUTC) systematic review of $\mathrm{RCTs}^{20}$ demonstrated that stroke patients who obtained treatment in a stroke rehabilitation unit are more likely to be alive and have a lower risk of being dependent compared with patients who obtained care in general wards. The results of this review also showed that stroke survivors may continue to benefit from intervention after the sub-acute phase. ${ }^{20}$ A recent systematic review that included 96 studies with 10,401 participants investigated the effects of different physical rehabilitation approaches. ${ }^{21}$ More than half of these studies were carried out in China. Of 96 included studies, 27 studies were on stroke rehabilitation, and all of them provided evidence on the effectiveness of stroke rehabilitation in improving functional recovery. Furthermore, 12 studies found stroke rehabilitation more effective in improving motor function compared with usual care.

Stroke rehabilitation in the outpatient setting. Outpatient stroke rehabilitation is defined as a type of treatment where patients go to a clinic or hospital to attend sessions and then return home the same day. ${ }^{22}$ However, for some economical and sociodemographic factors, along with an expanding number of stroke survivors, there is growing enthusiasm for outpatient stroke rehabilitation. ${ }^{23}$ Outpatient facilities can be components of a larger hospital facility and provide access to healthcare services including stroke 
rehabilitation programs. Patients regularly spend a few hours, frequently 3 days weekly at the facility in treatment sessions and return home afterward. ${ }^{23} \mathrm{~A}$ recent Canadian trial ${ }^{24}$ was conducted to investigate the role of a combination of outpatient and inpatient rehabilitation programs on cardiovascular fitness and walking ability. All 50 participating stroke patients received 60-minute physical therapy sessions 5 times weekly as inpatients for 6 weeks, and 3 times weekly as outpatients for another 6 weeks. They found that those patients who received the stroke rehab program including the body-weight-supported treadmill training had better outcomes compared with the usual stroke care. In a smaller pilot randomized trial, researchers investigated the effects of outpatient rehabilitation on walking and balance for patients with chronic stroke. ${ }^{11}$ Rehabilitation was provided for 4 weeks in a tertiary neurological hospital in China. The results suggested that short outpatient rehabilitation programs were viable in enhancing balance and walking function after stroke.

Stroke rehabilitation in the inpatient setting. An inpatient stroke rehabilitation facility is defined as a multidisciplinary team that exclusively oversees stroke patients in a ward at least one week after stroke. ${ }^{20}$ These facilities may be independent or constitute some portion of a larger hospital system. Patients stay in these facilities, generally for 2 to 3 weeks, and participate in comprehensive rehabilitation programs. Normally, these programs incorporate no less than 3 hours of element treatment per day, for 5 or 6 days a week. A previously published RCT conducted in Germany evaluated the effects of post-acute inpatient rehabilitation after stroke. ${ }^{25}$ All 30 participating stroke patients received treatment over a period of 2 weeks. Results from this trial indicated that inpatient stroke rehabilitation has positive effects on mobility. Furthermore, a pilot RCT from Australia aimed at testing motor and cognitive functions in patients with acute post-stroke after a cerebral infarction. ${ }^{26}$ All 44 participating stroke patients were randomly assigned to 5, one-hour sessions for one week of therapist-supervised practicing of daily tasks. The results of this study showed a major improvement in motor function. A more recent systematic review, was conducted to investigate which variables can predict functional independence at discharge from inpatient rehabilitation facilities. ${ }^{27}$ This review included 27 studies reporting Barthel Index (BI) or Functional Independence Measure (FIM) scores. The results summarized that functional ability improved in patients after post-stroke inpatient rehabilitation, and that this can be predicted by variables such as age and history of stroke.
Stroke rehabilitation in a nursing facility. A nursing facility (NF) is defined as a facility where a client is admitted, and services are provided by a multidisciplinary professional team, aimed at restoring function. ${ }^{28}$ These facilities differ technically, yet they provide some kind of rehabilitation services. If the service is provided, it is for fewer hours than the hospital setting as outlined above (approximately 4 hours per patient over 3-5 working days) in most NFs. ${ }^{28}$ Patients with stroke after the acute phase are referred either to independent rehabilitation centers or NFs based on sociodemographic and economic factors such as age, general conditions, and level of impairment. ${ }^{28} \mathrm{~A}$ small, but well-designed RCT from a single NF in St. Louis in the United States of America (USA), included 26 older patients. ${ }^{29}$ Patients were randomized to enhanced medical rehabilitation or standard-of-care rehabilitation. Along with functional outcomes, therapy intensity, and engagement were measured. The results from this trial found that NF patients in the intervention group had better functional outcomes, higher intensity, and patient engagement compared with the standard-of-care rehabilitation. A recent systematic review, ${ }^{30}$ included 19 articles, and examined the different predictive variables associated with discharge destination of acute stroke patients after hospitalization, including NFs. ${ }^{30}$ This review revealed that functional dependency or comorbidity was the main factor that influenced admission in a NF after acute care. The effect of other variables such as age, gender, and race differed between studies, and remains under debate.

Stroke rehabilitation in the home-based setting. Home-based stroke rehabilitation is characterized as a complex package of care provided by a clinician or nurse aiming at either avoiding the need for admission to hospital, or empowering timely and more virtual discharge and follow-up at home. ${ }^{31}$ Home-based rehabilitation takes into account extraordinary adaptability, such that patients can tailor their program of rehabilitation around their individual needs and schedules. This care is often most appropriate for individuals who require treatment by a standard rehabilitation professional. ${ }^{31}$ A previous trial on 71 therapy practices was conducted in northern Germany over 2 years to compare the effects of rehabilitation programs in homes or standard-of-care for patients with upper limb dysfunction after stroke. ${ }^{32}$ This trial included 156 patients, 85 of them were assigned to receive a rehabilitation program in their homes, and 71 patients were assigned standard therapy. This study revealed that home-based therapy was more effective than conventional therapy in improving quality of 
movement and motor function. A systematic review of 11 RCTs investigated the functional benefits of a home-based rehabilitation program for communitydwelling people with stroke. ${ }^{33}$ The results of this review demonstrated that home-based rehabilitation was very effective at 6 weeks and 3 months, but less clear at 6 months. Also, individual studies of this review reported increased care satisfaction in favor of home-based rehabilitation.

The role of telerehabilitation and technology for patients with stroke. Telerehabilitation is defined as the delivery of rehabilitation services including clinical assessment and clinical therapy over telecom systems, and the web. ${ }^{34}$ These are an alternative way of delivering stroke rehabilitation services using information and communication technologies between the healthcare professional and the patient in a remote area. These communications may occur through a variety of technologies such as the telephone, internet-based videoconferencing, and sensors such as pedometers. Virtual reality (VR) is one example for using technology for rehabilitation purposes, where the patient completes treatment inside a computer-produced virtual environment, and information is transmitted to the specialist. ${ }^{35}$ Virtual reality is defined as an interaction that allows users to interact with a multisensory stimulated environment and receive real time feedback on performance between advanced computer-technology and the users with a computer-generated environment in a naturalistic fashion. ${ }^{36}$ The use of VR has risen as a new treatment approach in stroke rehabilitation settings over the last 10 years. ${ }^{37}$ This approach might be advantageous as it provides an opportunity to practice activities that cannot be practiced inside the confines of a clinical environment. Furthermore, there are a few components of VR that may imply that patients invest more energy in treatment: for example, the activity might be more motivating. ${ }^{37} \mathrm{~A}$ study conducted in Spain ${ }^{38}$ was carried out to evaluate the clinical effectiveness of using VR as telerehabilitation program in improving balance after stroke. All 30 participating stroke patients received 20, 45-minute training sessions with the telerehabilitation program, conducted 3 times a week in the clinic or at home. The results revealed that VR based telerehabilitation programs promote the loco-motor skills associated with balance in the same way as in-clinic interventions. Similarly, a systematic review of $11 \mathrm{RCTs}^{39}$ on the effects of telerehabilitation on improving functions for patients with stroke in their homes, found limited to moderate evidence that telerehabilitation of all approaches has equal effects with conventional rehabilitation in improving ADL and motor functions, In another recent systematic review, ${ }^{37}$ RCTs were included to compare VR effects on upper limb functions and impact on gait, cognitive function, and ADL after stroke; with an alternative intervention or no intervention. The review's results found that VR was more effective than conventional therapy in improving upper limb function based on 12 studies, and significantly more effective than no therapy in improving upper limb function based on 9 studies. The use of VR also improved ADL function when compared to more conventional therapy approaches based on 8 studies. Furthermore, a systematic review with meta-analysis ${ }^{40}$ including 15 trials was published recently to compare the effects of VR based rehabilitation verses standard rehabilitation, or VR based rehabilitation added to the standard rehabilitation regimen. ${ }^{40}$ Some beneficial effects of VR based rehabilitation in walking speed, balance, and mobility outcomes in stroke survivors compared with standard rehabilitation were identified. The results also showed greater benefit in mobility when VR based rehabilitation was added to standard rehabilitation. On the other hand, there are many other technologies that can be used with stroke rehabilitation programs, such as using robotics. Robot-assisted rehabilitation is a developing technology field that aims to be utilized in the stroke rehabilitation setting. ${ }^{41}$ Robotic technology represents a highly repetitive and task-oriented feasible tool to administer in stroke rehabilitation. The potential of robotic technology in stroke rehabilitation might offer extensive advantages, not just regarding cost, but also for the researchers with an approach inspired from evidence-based practice. Evidence from a systematic review $^{42}$ that included 11 RCTs found that robotassisted therapy had similar effects to conventional therapy on upper limb motor recovery, strength, motor control, and ADL. ${ }^{42}$

Stroke rehabilitation outcome measures using the International Classification of Functioning, Disability, and Health model. There are many outcome measures to be used in stroke rehabilitation. ${ }^{43}$ In 2001, the WHO developed a framework for measuring health and disability at both the individual and population levels, called the International Classification of Functioning, Disability and Health, known more commonly as ICF (Figure 2). ${ }^{5}$ The ICF is a brief, important, and accurate instrument that can be used in stroke rehabilitation to provide a multi-dimensional approach to describing stroke patients functioning and disability, and to help to organize this information. ${ }^{44}$ Body functions can be defined as physiological functions of body systems, while activities and participation can be defined as execution of a task or action by an individual and involvement 


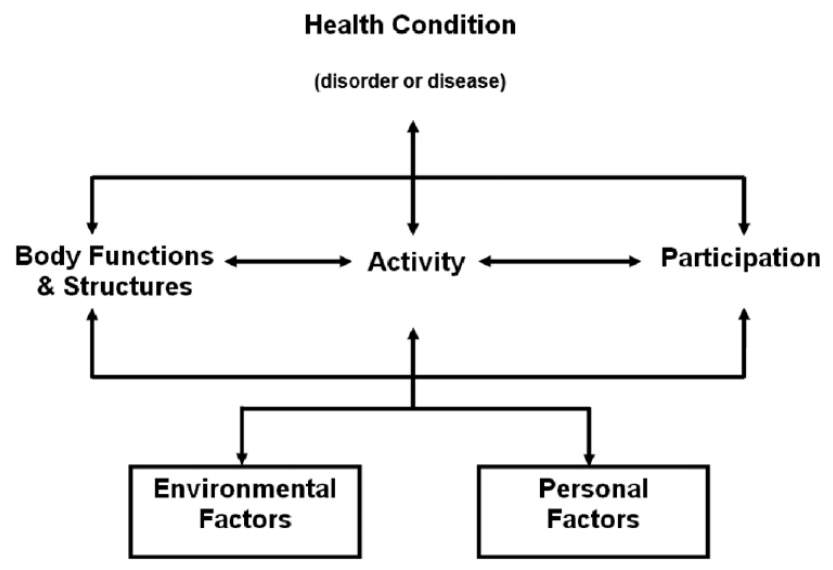

Figure 2 - Interactions between segments of the International Classification of Functioning, Disability, and Health model.

in a life situation. ${ }^{45}$ In Table 2 , we summarized all possible examples of measures that may be used in stroke rehabilitation in any settings, according to the 3 ICF domains. All of these measures were then described with some details such as objectives, advantages, and disadvantages in Appendix 1.
General recommendations to improve stroke rehabilitation programs in Saudi Arabia. From this review, the optimal stroke rehabilitation parameters (frequency, type, duration, intensity) could not be established. It will continue to be a major healthcare provocation in Saudi Arabia. However, many components of the stroke burden can be prevented and managed, including implementing the following recommendations for rehabilitation professionals, policy makers, and for future research:

1. Recommendations for rehabilitation professionals. Rehabilitation professionals such as physical/ occupational therapists and others in Saudi Arabia are not necessarily well trained in managing patients with stroke. Therefore, we believe there is a need for strengthening education in stroke rehabilitation in the curricula for all health care professionals, including education on the specific topics related to stroke prevention, management, and rehabilitation. To be able to offer high quality services for patients with stroke, post-professional programs should be introduced and supervised by the Saudi Commission for Health Specialties. We believe it is time for professionals such as

Table 2 - A selection of outcome measures that have demonstrated construct validity in stroke rehabilitation by using the International Classification of Functioning, Disability, and Health domains. ${ }^{44,45}$

\begin{tabular}{|c|c|c|}
\hline Body structure and function & Activities & Participation \\
\hline 1. Beck Depression Inventory & 1. Action Research Arm Test & 1. Canadian Occupational Performance Measure \\
\hline 2. Behavioral Inattention Test & 2. Barthel Index & 2. EuroQoL Quality of Life Scale \\
\hline 3. Canadian Neurological Scale & 3. Berg Balance Scale & 3. Assessment of Life Habits (LIFE-H) \\
\hline 4. Clock Drawing Test & 4. Box and Block Test & 4. London Handicap Scale \\
\hline 5. Frenchay Aphasia Screening Test & $\begin{array}{l}\text { 5. Chedoke McMaster Stroke Assessment } \\
\text { Scale }\end{array}$ & 5. Medical Outcomes Study Short-Form 36 \\
\hline 6. Fugl-Meyer Assessment & $\begin{array}{l}\text { 6. Chedoke Arm and Hand Activity } \\
\text { Inventory }\end{array}$ & 6. Nottingham Health Profile \\
\hline 7. General Health Questionnaire-28 & 7. Clinical Outcome Variables Scale & 7. Reintegration to Normal Living Index \\
\hline 8. Geriatric Depression Scale & 8. Functional Independence Measure & 8. Stroke Adapted Sickness Impact Profile \\
\hline 9. Hospital Anxiety and Depression Scale & 9. Frenchay Activities Index & 9. Stroke Impact Scale \\
\hline 10. Line Bisection Test & 10. Motor Assessment Scale & 10. Stroke Specific Quality of Life \\
\hline 11. Mini-Mental State Examination & 11. Nine-hole Peg Test & \\
\hline 12. Modified Ashworth Scale & 12. Rankin Handicap Scale & \\
\hline 13. Montreal Cognitive Assessment & 13. Rivermead Mobility Scale & \\
\hline 14. Motor-free Visual Perception Test & 14. Rivermead Motor Assessment & \\
\hline 15. National Institutes of Health Stroke Scale & 15. Six-Minute Walk Test & \\
\hline 16. Orpington Prognostic Scale & 16. Timed Up and Go & \\
\hline \multirow[t]{2}{*}{ 17. Stroke Rehabilitation Assessment of Movement } & 17. Wolf Motor Function Test & \\
\hline & 18. Dynamic Gait Index & \\
\hline
\end{tabular}


physical therapists in Saudi Arabia to establish residency and fellowship programs, especially those that work with patients with stroke such as neurology and geriatrics. ${ }^{46}$ One of the challenges for rehabilitation professionals is using evidence-based practice. Continuing education is an important factor in providing high quality services for patients with stroke and other conditions. ${ }^{47}$ Therefore, it is important for all members of the rehab team involved in managing patients with stroke to be trained in evidence-based practice though continuing education activities. ${ }^{48}$

2. Recommendations for policy makers. Policy makers can play a major role toward translating science into practice in the field of stroke care. For better health care services for patients with stroke in Saudi Arabia, we believe there is a need for a national framework to help guide the utilization and generation of evidence to support decision making for complex, multifactorial public health challenges, including stroke prevention, management, and rehabilitation. This national framework will close the evidence-to-practice gap on the national level, by increasing the dissemination of evidence-based stroke rehabilitation findings between the rehabilitation professionals, other health care professionals, policymakers, and the public in general. Furthermore, research funders such as King Abdulaziz for Sciences and Technology and others, should increase opportunities for those carrying out stroke research to encourage them to measure and share their outcomes so others can learn from their experience, especially in rural areas. The funders also need to encourage collaboration among researchers in a variety of disciplines to ensure a feasible and appropriate evaluation for stroke care on the national level, including rehabilitation services. For patients with stroke especially in the acute stage, there is a need to improve the accessibility of health care facilities and stroke teams to ensure better outcome. The Ministry of Health and other providers should issue and widely disseminate guidelines for health care professional on stroke care, and best practice at different stages of the disease. ${ }^{49}$ These organizations should also encourage the use of the ICF model in all settings to ease communication and benchmarking on a national and international level regarding functioning, disability, and health. ${ }^{50}$

3. Recommendations for future research. For future research, we believe there is a need to improve the quality of conduct and reporting of national studies on stroke rehabilitation programs. Researchers from Saudi Arabia should consider using reporting guidelines such as the CONSORT, PRISMA, and STROBE to improve the quality of reporting. ${ }^{51}$ For example, researchers of future trials should follow the CONSORT guidelines to help in improving the quality of conducting, analyzing, and reporting results of the trials. Also, such guidelines help in minimizing bias (for example, randomization sequence generation, treatment allocation concealment, blinding, incomplete outcome data, and selective outcome reporting).

Future research in Saudi Arabia on stroke rehabilitation topics should address some of the following questions:

1. What is the current status of stroke rehabilitation services and needs?

2. What are the costs associated with stroke rehabilitation in different settings; and will using technology (such as VR) in the rehabilitation setting improve the efficiency?

3. Is there geographic variation in the quality of stroke care, including rehabilitation services?

4. Is a standardized measure for patients with stroke in different settings; for example, the ICF model, reliable and valid for use in Saudi hospitals and rehabilitation centers?

5. By using a national standardized measure for patients with stroke, do outcomes vary across the different rehabilitation settings, after adjusting for covariates?

6. For different patients with stroke (in different stages: acute, sub-acute, chronic), what is the effectiveness of rehabilitation programs that incorporate any of the following strategies: electrical stimulation, robotics, constraint-induced movement therapy, repetitive task practice, and motor imagery?

7. What role do environmental factors play on disability among patients with stroke?

In conclusion, stroke in Saudi Arabia will continue to be a major health problem associated with a higher risk of morbidity, disability, and mortality, unless the healthcare system introduces improved prevention, management, and rehabilitation services. A stroke rehabilitation program is incredibly complex, yet appears to be effective in improving patients' quality of life and functional status. The growing evidence for the use of technology in stroke rehabilitation has been shown to be visible and safe in any setting, such as outpatient, inpatients, nursing facilities, and others. To measure the impact of these rehabilitation programs in these settings and to ensure successful implementation, measuring of outcomes is essential. The ICF-WHO model is highly recommended by international organizations to be used to provide a standardized framework in measuring functioning and disability. Finally, in this call to action paper, we have suggested some recommendations for stroke rehabilitation professionals including scientists, clinicians, and policy makers. 
Acknowledgments. The authors extend their appreciation for support to the Research Center, College of Applied Medical Sciences and the Deanship of Scientific Research at King Saud University.

\section{References}

1. Robert AA, Zamzami MM. Stroke in Saudi Arabia: a review of the recent literature. Pan Afr Med J 2014; 17: 14.

2. Gershkoff A, Moon D, Fincke A, Dangaria H. Stroke Rehabilitation. In: Belval B, Lebowitz. H, editors. Current Diagnosis \& Treatment: Physical Medicine \& Rehabilitation. Columbus (OH): McGraw-Hill Global Education; 2015.

3. Benamer HT, Grosset D. Stroke in Arab countries: a systematic literature review. I Neurol Sci 2009; 284: 18-23.

4. Al Khathaami AM, Algahtani H, Alwabel A, Alosherey N, Kojan S, Aljumah M. The status of acute stroke care in Saudi Arabia: an urgent call for action! Int J Stroke 2011; 6: 75-76.

5. Silva SM, Corrêa FI, Faria CD, Buchalla CM, Silva PF, Corrêa JC. Evaluation of post-stroke functionality based on the International Classification of Functioning, Disability, and Health: a proposal for use of assessment tools. J Phys Ther Sci 2015; 27: 1665-1670.

6. Sundseth A, Thommessen B, Ronning OM. Outcome after mobilization within 24 hours of acute stroke: a randomized controlled trial. Stroke 2012; 43: 2389-2394.

7. Morreale M, Marchione P, Pili A, Lauta A, Castiglia SF, Spallone A, et al. Early versus delayed rehabilitation treatment in hemiplegic patients with ischemic stroke: proprioceptive or cognitive approach? Eur J Phys Rehabil Med 2016; 52: 81-89.

8. O'Sullivan SB, Schmitz TJ, Fulk GD, editors. Physical rehabilitation. 6th ed. Philadelphia (PA): F.A. Davis Co; 2014.

9. Fjærtoft H, Rohweder G, Indredavik B. Stroke unit care combined with early supported discharge improves 5-year outcome: a randomized controlled trial. Stroke 2011; 42: $1707-1711$.

10. Langhorne P, Fearon P, Ronning OM, Kaste M, Palomaki $\mathrm{H}$, Vemmos K, et al. Stroke unit care benefits patients with intracerebral hemorrhage: systematic review and meta-analysis. Stroke 2013; 44: 3044-3049.

11. Zhu Z, Cui L, Yin M, Yu Y, Zhou X, Wang H, et al. Hydrotherapy vs. conventional land-based exercise for improving walking and balance after stroke: a randomized controlled trial. Clin Rehabil 2016; 30: 587-593.

12. Clarke DJ, Forster A. Improving post-stroke recovery: the role of the multidisciplinary health care team. J Multidiscip Healthc 2015; 8: 433-442.

13. Graham LA. Organization of rehabilitation services. Handb Clin Neurol 2013; 110: 113-120.

14. Page SJ, Schmid A, Harris JE. Optimizing terminology for stroke motor rehabilitation: recommendations from the American Congress of Rehabilitation Medicine Stroke Movement Interventions Subcommittee. Arch Phys Med Rehabil 2012; 93: 1395-1399.

15. Bernhardt J, Churilov L, Ellery F, Collier J, Chamberlain J, Langhorne P, et al. Prespecified dose-response analysis for A Very Early Rehabilitation Trial (AVERT). Neurology 2016; 86: 2138-2145.

16. Knecht S, Hesse S, Oster P. Rehabilitation after stroke. Dtsch Arztebl Int 2011; 108: 600-606.

17. Tyson S, Wilkinson J, Thomas N, Selles R, McCabe C, Tyrrell $\mathrm{P}$, et al. Phase II Pragmatic Randomized Controlled Trial of Patient-Led Therapies (Mirror Therapy and Lower-Limb Exercises) During Inpatient Stroke Rehabilitation. Neurorehabil Neural Repair 2015; 29: 818-826.
18. Chan DK, Levi C, Cordato D, O’Rourke F, Chen J, Redmond $\mathrm{H}$, et al. Health service management study for stroke: a randomized controlled trial to evaluate two models of stroke care. Int J Stroke 2014; 9: 400-405.

19. Pandian S, Arya KN, Kumar D. Does motor training of the nonparetic side influences balance and function in chronic stroke? A pilot RCT. ScientificWorldJournal 2014; 2014: 769726.

20. Stroke Unit Trialists' Collaboration. Organised inpatient (stroke unit) care for stroke. Cochrane Database Syst Rev 2013; 9: CD000197.

21. Pollock A, Baer G, Campbell P, Choo PL, Forster A, Morris J, et al. Physical rehabilitation approaches for the recovery of function and mobility following stroke. Cochrane Database Syst Rev 2014; 4: CD001920.

22. Visser MM, Heijenbrok-Kal MH, Spijker AV, Oostra KM, Busschbach JJ, Ribbers GM. Coping, problem solving, depression, and health-related quality of life in patients receiving outpatient stroke rehabilitation. Arch Phys Med Rehabil 2015; 96: 1492-1498.

23. Langhorne P, Bernhardt J, Kwakkel G. Stroke rehabilitation. Lancet 2011; 377: 1693-1702.

24. Mackay-Lyons M, McDonald A, Matheson J, Eskes G, Klus MA. Dual effects of body-weight supported treadmill training on cardiovascular fitness and walking ability early after stroke: a randomized controlled trial. Neurorehabil Neural Repair 2013; 27: 644-653.

25. Tripp F, Krakow K. Effects of an aquatic therapy approach (Halliwick-Therapy) on functional mobility in subacute stroke patients: a randomized controlled trial. Clin Rehabil 2014; 28: 432-439.

26. Liu KP, Chan CC. Pilot randomized controlled trial of selfregulation in promoting function in acute poststroke patients. Arch Phys Med Rehabil 2014; 95: 1262-1267.

27. Meyer MJ, Pereira S, McClure A, Teasell R, Thind A, Koval J, et al. A systematic review of studies reporting multivariable models to predict functional outcomes after post-stroke inpatient rehabilitation. Disabil Rehabil 2015; 37: 1316-1323.

28. Koopmans RT, Lavrijsen JC, Hoek JF, Went PB, Schols JM. Dutch elderly care physician: a new generation of nursing home physician specialists. J Am Geriatr Soc 2010; 58: 1807-1809.

29. Lenze EJ, Host HH, Hildebrand MW, Morrow-Howell N, Carpenter B, Freedland KE, et al. Enhanced medical rehabilitation increases therapy intensity and engagement and improves functional outcomes in postacute rehabilitation of older adults: a randomized-controlled trial. J Am Med Dir Assoc 2012; 13: 708-712.

30. Mees M, Klein J, Yperzeele L, Vanacker P, Cras P. Predicting discharge destination after stroke: A systematic review. Clin Neurol Neurosurg 2016; 142: 15-21.

31. Allen L, Richardson M, McIntyre A, Janzen S, Meyer M, Ure $\mathrm{D}$, et al. Community stroke rehabilitation teams: providing home-based stroke rehabilitation in Ontario, Canada. Can J Neurol Sci 2014; 41: 697-703.

32. Barzel A, Ketels G, Stark A, Tetzlaff B, Daubmann A, Wegscheider $\mathrm{K}$, et al. Home-based constraint-induced movement therapy for patients with upper limb dysfunction after stroke (HOMECIMT): a cluster-randomised, controlled trial. Lancet Neurol 2015; 14: 893-902.

33. Hillier S, Inglis-Jassiem G. Rehabilitation for communitydwelling people with stroke: home or centre based? A systematic review. Int J Stroke 2010; 5: 178-186. 
34. Pierce LL, Steiner V, Smelser J. Stroke caregivers share ABCs of caring. Rehabil Nurs 2009; 34: 200-208.

35. Demain S, Burridge J, Ellis-Hill C, Hughes AM, Yardley L, Tedesco-Triccas L, et al. Assistive technologies after stroke: selfmanagement or fending for yourself? A focus group study. BMC Health Serv Res 2013; 13: 334.

36. Saposnik G, Levin M; Outcome Research Canada (SORCan) Working Group. Virtual reality in stroke rehabilitation: a meta-analysis and implications for clinicians. Stroke 2011; 42: $1380-1386$.

37. Laver KE, George S, Thomas S, Deutsch JE, Crotty M. Virtual reality for stroke rehabilitation. Cochrane Database Syst Rev 2015; 2: CD008349.

38. Lloréns R, Noé E, Colomer C, Alcañiz M. Effectiveness, usability, and cost-benefit of a virtual reality-based telerehabilitation program for balance recovery after stroke: a randomized controlled trial. Arch Phys Med Rehabil 2015; 96: 418-425.

39. Chen J, Jin W, Zhang XX, Xu W, Liu XN, Ren CC. Telerehabilitation Approaches for Stroke Patients: Systematic Review and Meta-analysis of Randomized Controlled Trials. J Stroke Cerebrovasc Dis 2015; 24: 2660-2668.

40. Corbetta D, Imeri F, Gatti R. Rehabilitation that incorporates virtual reality is more effective than standard rehabilitation for improving walking speed, balance and mobility after stroke: a systematic review. J Physiother 2015; 61: 117-124.

41. Poli P, Morone G, Rosati G, Masiero S. Robotic technologies and rehabilitation: new tools for stroke patients' therapy. Biomed Res Int. 2013; 2013: 153872 .

42. Norouzi-Gheidari N, Archambault PS, Fung J. Effects of robot-assisted therapy on stroke rehabilitation in upper limbs: systematic review and meta-analysis of the literature. J Rehabil Res Dev 2012; 49: 479-496.

43. Baker K, Cano SJ, Playford ED. Outcome measurement in stroke: a scale selection strategy. Stroke 2011; 42: 1787-1794.

44. Quintas R, Cerniauskaite M, Ajovalasit D, Sattin D, Boncoraglio G, Parati EA, et al. Describing functioning, disability, and health with the International Classification of Functioning, Disability, and Health Brief Core Set for Stroke. Am J Phys Med Rehabil 2012; 91: S14-S21.

45. Lemberg I, Kirchberger I, Stucki G, Cieza A. The ICF Core Set for stroke from the perspective of physicians: a worldwide validation study using the Delphi technique. Eur J Phys Rehabil Med 2010; 46: 377-388.

46. Bindawas SM. Physical Therapy Entry-level Education and Post-professional Training in Saudi Arabia: A Comparison of Perceptions of Physical Therapists from Five Regions. J Phys Ther Sci 2014; 26: 1377-1382.

47. Hoving JL, Kok R, Ketelaar SM, Smits PB, van Dijk FJ, Verbeek $\mathrm{JH}$. Improved quality and more attractive work by applying EBM in disability evaluations: a qualitative survey. BMC Med Educ 2016; 16: 77.

48. Bindawas SM. Evidence-based Health Care Continuing Education Seminars Improve Academic Staff Knowledge and Attitudes in Saudi Arabia. Pak J Med Sci 2013; 29: 703-709.

49. Meschia JF, Bushnell C, Boden-Albala B, Braun LT, Bravata DM, Chaturvedi $S$, et al. Guidelines for the primary prevention of stroke: a statement for healthcare professionals from the American Heart Association/American Stroke Association. Stroke 2014; 45: 3754-832.

50. Mayo NE, Poissant L, Ahmed S, Finch L, Higgins J, Salbach $\mathrm{NM}$, et al. Incorporating the International Classification of Functioning, Disability, and Health (ICF) into an electronic health record to create indicators of function: proof of concept using the SF-12. J Am Med Inform Assoc. 2004; 11: 514-522.
51. Knüppel H, Metz C, Meerpohl JJ, Strech D. How psychiatry journals support the unbiased translation of clinical research. A cross-sectional study of editorial policies. PLoS One 2013; 8: e75995.

52. Enderby PM, Wood VA, Wade DT, Hewer RL. The Frenchay Aphasia Screening Test: a short, simple test for aphasia appropriate for non-specialists. Int Rehabil Med 1987; 8: 166-170

53. Gladstone DJ, Danells CJ, Black SE. The fugl-meyer assessment of motor recovery after stroke: a critical review of its measurement properties. Neurorehabil Neural Repair 2002; 16: 232-240.

54. Zigmond AS, Snaith RP. The hospital anxiety and depression scale. Acta Psychiatr Scand 1983; 67: 361-370.

55. Gregson JM, Leathley M, Moore AP, Sharma AK, Smith TL, Watkins CL. Reliability of the Tone Assessment Scale and the modified Ashworth scale as clinical tools for assessing poststroke spasticity. Arch Phys Med Rehabil 1999; 80: 1013-1016.

56. Tombaugh TN, McIntyre NJ. The mini-mental state examination: a comprehensive review. J Am Geriatr Soc 1992; 40: 922-935.

57. Keith RA, Granger CV, Hamilton BB, Sherwin FS. The functional independence measure: a new tool for rehabilitation. Adv Clin Rehabil 1987; 1: 6-18.

58. Mahoney FI, Barthel DW. Functional evaluation: the Barthel index. Md State Med J 1965; 14: 61-65.

59. Van der Lee JH, De Groot V, Beckerman H, Wagenaar RC, Lankhorst GJ, Bouter LM. The intra- and interrater reliability of the action research arm test: a practical test of upper extremity function in patients with stroke. Arch Phys Med Rehabil 2001; 82: 14-19.

60. Carr JH, Shepherd RB, Nordholm L, Lynne D. Investigation of a new motor assessment scale for stroke patients. Phys Ther 1985; 65: 175-180.

61. Dunn A, Marsden DL, Nugent E, Van Vliet P, Spratt NJ, Attia J, et al. Protocol variations and six-minute walk test performance in stroke survivors: a systematic review with meta-analysis. Stroke Res Treat 2015; 2015: 484813.

62. Duncan PW, Wallace D, Lai SM, Johnson D, Embretson S, Laster LJ. The stroke impact scale version 2.0. Evaluation of reliability, validity, and sensitivity to change. Stroke 1999; 30: 2131-2140.

63. Anderson C, Laubscher S, Burns R. Validation of the Short Form 36 (SF-36) health survey questionnaire among stroke patients. Stroke 1996; 27: 1812-1816.

64. Ebrahim S, Barer D, Nouri F. Use of the Nottingham Health Profile with patients after a stroke. J Epidemiol Community Health 1986; 40: 166-169.

65. Wood-Dauphinee SL, Opzoomer MA, Williams JI, Marchand B, Spitzer WO. Assessment of global function: The Reintegration to Normal Living Index. Arch Phys Med Rehabil 1988; 69: 583-590.

66. Brooks R. EuroQol: the current state of play. Health Policy 1996; 37: 53-72. 
Appendix 1 - Difference between the uses of outcome measures in stroke rehabilitation,

\begin{tabular}{|c|c|c|c|c|c|}
\hline Name & $\begin{array}{c}\text { Number of } \\
\text { citations }\end{array}$ & Purpose & Description & Advantages & Disadvantages \\
\hline $\begin{array}{l}\text { Frenchay Aphasia } \\
\text { Screening Test } \\
(\text { FAST) })^{52}\end{array}$ & 240 & $\begin{array}{c}\text { Screening device } \\
\text { to identify patients } \\
\text { with communication } \\
\text { difficulties }\end{array}$ & $\begin{array}{l}\text { FAST evaluates languages } \\
\text { in } 4 \text { noteworthy ranges: } \\
\text { appreciation, verbal } \\
\text { expression, perusing, and } \\
\text { composing. } \\
\text { Testing is engaged around } \\
\text { a solitary, twofold sided } \\
\text { jolt card delineating a } \\
\text { riverside scene on one side } \\
\text { and geometric shapes on } \\
\text { the other and } 5 \text { composed } \\
\quad \text { sentences. } \\
\text { Scores from every test } \\
\text { territory are summed to } \\
\text { obtain an aggregate score } \\
\text { out of } 30 \text {. Ten points are } \\
\text { accessible for each of the } \\
\text { cognizance and verbal } \\
\text { expression; } 5 \text { each for } \\
\text { perusing and composing }\end{array}$ & $\begin{array}{l}\text { Interpretability: Age- } \\
\text { stratified regulation of } \\
\text { information is accessible; } \\
\text { taking into account the } \\
\text { appraisal of } 123 \text { people } \\
\text { aged } 20 \text { to } 81+. \\
\text { Acceptability: FAST is } \\
\text { short and straightforward, } \\
\text { requiring less than } 10 \\
\text { minutes of management. } \\
\text { Feasibility: FAST is easy to } \\
\text { regulate notwithstanding } \\
\text { during a bedside } \\
\text { assessment. Test materials } \\
\text { are straightforward and } \\
\text { portable }\end{array}$ & $\begin{array}{l}\text { The specificity of FAST } \\
\text { appears, by all accounts, } \\
\text { to be antagonistically } \\
\text { influenced by the vicinity } \\
\text { of visual field shortfalls, } \\
\text { visual disregard or } \\
\text { distractedness, lack of } \\
\text { education, deafness, poor } \\
\text { focus or confusion }\end{array}$ \\
\hline $\begin{array}{l}\text { Fugl-Meyer } \\
\text { Assessment of Motor } \\
\text { Recovery after Stroke } \\
(\text { FMA })^{53}\end{array}$ & 656 & $\begin{array}{l}\text { The FMA is intended } \\
\text { to evaluate motor } \\
\text { function, balance, } \\
\text { sensation qualities, } \\
\text { and joint function in } \\
\text { hemiplegic post-stroke } \\
\text { patients }\end{array}$ & $\begin{array}{l}\text { The scale consists of } 5 \\
\text { areas; motor function, } \\
\text { sensory function, balance, } \\
\text { joint range of motion and } \\
\text { joint pain. } \\
\text { Scale items are scored on } \\
\text { the premise of capacity to } \\
\text { complete the item utilizing } \\
\text { a } 3 \text {-point ordinal scale } \\
\text { where } 0=\text { cannot perform, } \\
1=\text { performs in part, and } \\
2=\text { performs completely. } \\
\text { The total possible scale } \\
\text { score is } 226 \text { (100 for } \\
\text { engine capacity; } 24 \text { for } \\
\text { sensation; } 14 \text { for parity; } \\
44 \text { for scope of movement; } \\
\text { and } 44 \text { for joint pain) }\end{array}$ & $\begin{array}{l}\text { Interpretability: The } \\
\text { interpretability of the } \\
\text { FMA is improved by the } \\
\text { scale's strong establishment } \\
\text { in all around characterized } \\
\text { phases of motor recovery. } \\
\text { It is broadly utilized and } \\
\text { globally acknowledged. } \\
\text { Acceptability: } \\
\text { Administration of the } \\
\text { entire test can be a long } \\
\text { process; it takes 30-45 } \\
\text { minutes. } \\
\text { Feasibility: The FMA } \\
\text { should be regulated by } \\
\text { a prepared physical or } \\
\text { occupational therapist. } \\
\text { Particular equipment is } \\
\text { not required; it is managed } \\
\text { over an assortment of } \\
\text { settings and can be used in } \\
\text { longitudinal assessments }\end{array}$ & $\begin{array}{l}\text { Need a prepared specialist. } \\
\text { Takes significantly more } \\
\text { time for evaluations }\end{array}$ \\
\hline $\begin{array}{l}\text { Hospital Anxiety } \\
\text { and Depression Scale } \\
(\text { HADS })^{54}\end{array}$ & 20593 & $\begin{array}{l}\text { A bi-dimensional } \\
\text { scale was developed } \\
\text { specifically to } \\
\text { recognize instances of } \\
\text { depression and anxiety } \\
\text { disorders among } \\
\text { physically sick patients }\end{array}$ & $\begin{array}{l}\text { The HADS consists of } \\
14 \text { items isolated into } \\
2 \text { subscales of } 7 \text { items } \\
\text { each: the anxiety subscale } \\
\text { (HADS-An) and the } \\
\text { depression subscale } \\
\text { (HADS-D). } \\
\text { The respondent rates every } \\
\text { item on a 4-point scale } \\
\text { extending from } 0 \text { (absence) } \\
-3 \text { (extreme presence). } \\
\text { Five of the } 14 \text { items were } \\
\text { coded in reverse. } \\
\text { The aggregate scale score } \\
\text { is out of } 42 \text { or } 21 \text { for } \\
\text { each of the subscales. } \\
\text { Higher scores showed } \\
\text { more noteworthy levels of } \\
\text { anxiety or depression }\end{array}$ & $\begin{array}{c}\text { Interpretability: No } \\
\text { standards are accessible in } \\
\text { English. } \\
\text { Acceptability: The scale is } \\
\text { convenient and simple to } \\
\text { utilize ( } 2-6 \text { minutes). } \\
\text { Feasibility: The HADS is } \\
\text { easy to utilize and score }\end{array}$ & $\begin{array}{l}\text { No institutionalization } \\
\text { for age or gender has been } \\
\text { performed. } \\
\text { Cut-off focuses utilized } \\
\text { are not specifically well } \\
\text { established }\end{array}$ \\
\hline
\end{tabular}


Appendix 1 - Difference between the uses of outcome measures in stroke rehabilitation continued.

\begin{tabular}{|c|c|c|c|c|c|}
\hline $\begin{array}{l}\text { Modified Ashworth } \\
\text { Scale }^{55}\end{array}$ & 257 & $\begin{array}{l}\text { To evaluate the } \\
\text { adequacy of hostile to } \\
\text { spastic medication in } \\
\text { patients experiencing } \\
\text { different sclerosis }\end{array}$ & $\begin{array}{l}\text { The unique Ashworth scale } \\
\text { consists of } 5 \text { evaluations } \\
\text { from } 0-4 .(0=\text { no } \\
\text { increment in muscle tone; } \\
1 \text { = slight increment in } \\
\text { muscle tone; } 1^{*}=\text { slight } \\
\text { increment in muscle } \\
\text { tone; } 2 \text { = more stamped } \\
\text { increment in muscle tone; } \\
3 \text { = significant increases } \\
\text { in muscle tone; } 4= \\
\text { influenced part unbending } \\
\text { in flexion or expansion) }\end{array}$ & $\begin{array}{l}\text { Interpretability: The first } \\
\text { Ashworth and Adjusted } \\
\text { Ashworth scales are } \\
\text { essential clinical measures } \\
\text { of tone. } \\
\text { Acceptability: While testing } \\
\text { should be moderately } \\
\text { concise, control of the } \\
\text { affected appendage/joint } \\
\text { may be uncomfortable for } \\
\text { patients. } \\
\text { Feasibility: No particular } \\
\text { equipment is required }\end{array}$ & $\begin{array}{l}\text { Lower levels of unwavering } \\
\text { quality. In investigations } \\
\text { of post-stroke patients, the } \\
\text { most widely recognized } \\
\text { appraisals reported are } \\
0,1 \text {, and } 1+\text {. The largest } \\
\text { amounts of between } \\
\text { spectator and intra- } \\
\text { observer assertion are } \\
\text { noted among patients with } \\
\text { a } 0 \text { rating }\end{array}$ \\
\hline $\begin{array}{l}\text { Mini-Mental } \\
\text { State Examination } \\
\left(_{\text {MMSE) }}^{56}\right.\end{array}$ & 2771 & $\begin{array}{c}\text { The MMSE was } \\
\text { created as a brief } \\
\text { screening instrument } \\
\text { to provide a } \\
\text { quantitative appraisal } \\
\text { of intellectual } \\
\text { disability and to record } \\
\text { subjective changes } \\
\text { after some time }\end{array}$ & $\begin{array}{l}\text { The MMSE consists of } 11 \\
\text { basic inquiries or errands. } \\
\text { These are assembled } \\
\text { into } 7 \text { cognitive spaces; } \\
\text { introduction to time, } \\
\text { introduction to place, } \\
\text { enrollment of } 3 \text { words, } \\
\text { consideration and } \\
\text { computation, review of } 3 \\
\text { words, language, and visual } \\
\text { development. } \\
\text { A score of } 23 / 24 \text { is the } \\
\text { most acknowledged cut-off } \\
\text { point showing the presence } \\
\text { of cognitive impairment }\end{array}$ & $\begin{array}{l}\text { Interpretability: The } \\
\text { MMSE is broadly } \\
\text { utilized and the most } \\
\text { acknowledged part was the } \\
\text { cut-off scores, which were } \\
\text { demonstrative of cognitive } \\
\text { impairment. } \\
\text { Acceptability: The } \\
\text { test is brief, requiring } \\
\text { approximately } 10 \text { minutes } \\
\text { to complete. } \\
\text { Feasibility: The test requires } \\
\text { no specific equipment, } \\
\text { requires little time and is } \\
\text { inexpensive }\end{array}$ & $\begin{array}{l}\text { It is unrealistic to } \\
\text { distinguish adequate cut- } \\
\text { off scores for visual or } \\
\text { verbal memory issues } \\
\text { Low reported levels of } \\
\text { affectability among stroke } \\
\text { patients }\end{array}$ \\
\hline $\begin{array}{l}\text { Functional } \\
\text { Independence } \\
\text { Measure (FIM) }\end{array}$ & 1293 & $\begin{array}{l}\text { Measures the level } \\
\text { of understanding } \\
\text { the disability and } \\
\text { demonstrates the } \\
\text { amount of help } \\
\text { required for the person } \\
\text { to complete the } \\
\text { movement of activity } \\
\text { of daily living (ADL) }\end{array}$ & $\begin{array}{l}\text { Consists of } 18 \text { items: } \\
13 \text { motor assignments } \\
\text { and } 5 \text { cognitive errands } \\
\text { (considered fundamental } \\
\text { ADL). } \\
\text { Tasks are evaluated on a } \\
7 \text { point ordinal scale that } \\
\text { ranges in total assistance } \\
\text { (or complete dependence) } \\
\text { to complete independence. } \\
\text { Scores range from } 18 \\
\text { (least) to } 126 \text { (most } \\
\text { elevated demonstrating } \\
\text { level of function). } \\
\text { Scores are for the most part } \\
\text { appraised upon admission } \\
\text { and discharge }\end{array}$ & $\begin{array}{l}\text { FIM survey the ADL } \\
\text { FIM is used to assess } \\
\text { impairment among adults } \\
\text { (18-64 years); Elderly } \\
\text { adults ( } 65 \text { years or older). } \\
\text { FIM is utilized to assess } \\
\text { mind damage, geriatrics, } \\
\text { various sclerosis; } \\
\text { orthopedic conditions } \\
\text { including low back } \\
\text { pain, spinal cord harm } \\
\text { and stroke persistent } \\
\text { individuals. } \\
\text { Excellent test-retest } \\
\text { dependability. } \\
\text { FIM has high inward } \\
\text { consistency and } \\
\text { satisfactory discriminative } \\
\text { abilities for rehabilitation } \\
\text { patients }\end{array}$ & $\begin{array}{c}\text { Standard error of } \\
\text { estimationn mean } \\
\text { (SEM) and insignificant } \\
\text { recognizable. Change not } \\
\text { built up. } \\
\text { There is no cut-off scores. } \\
\text { FIM is not freely accessible }\end{array}$ \\
\hline Bathel Index $(\mathrm{BI})^{58}$ & 10962 & $\begin{array}{c}\text { Evaluates the capacity } \\
\text { of a person with a } \\
\text { neuromuscular or } \\
\text { musculoskeletal } \\
\text { disorder to standard } \\
\text { care }\end{array}$ & $\begin{array}{l}10 \text { ADL exercises } \\
\text { including feeding, bathing, } \\
\text { grooming, dressing, bowel } \\
\text { control, bladder control, } \\
\text { toileting, chair transfer, } \\
\text { ambulation, stair climbing. } \\
\text { Items are appraised based } \\
\text { on the measure of help } \\
\text { required to complete every } \\
\text { activity }\end{array}$ & $\begin{array}{l}\text { Area of evaluation } \\
\text { incorporates ADL; } \\
\text { functional mobility; gait. } \\
\text { It sets aside less time to } \\
\text { complete the evaluation. } \\
\text { It is an execution based } \\
\text { measure. Equipment and } \\
\text { preparation not required }\end{array}$ & $\begin{array}{l}\text { Test-retest reliability not } \\
\text { established }\end{array}$ \\
\hline
\end{tabular}


Appendix 1 - Difference between the uses of outcome measures in stroke rehabilitation continued.

\begin{tabular}{|c|c|c|c|c|c|}
\hline $\begin{array}{l}\text { Action Research Arm } \\
\text { Test (ARAT) }{ }^{59}\end{array}$ & 275 & $\begin{array}{l}\text { The ARAT is a } \\
\text { spectator appraised, } \\
\text { execution based } \\
\text { evaluation of upper } \\
\text { extremity function and } \\
\text { aptitude }\end{array}$ & $\begin{array}{l}\text { The ARAT has only } 19 \\
\text { items, which are assembled } \\
\text { into } 4 \text { subsets: grasp ( } 6 \\
\text { items), grip ( } 4 \text { items), } \\
\text { pinch ( } 6 \text { items), and gross } \\
\text { movement ( } 3 \text { items). } \\
\text { All items are evaluated } \\
\text { on a 4-point ordinal scale } \\
\text { going from } 0 \text { to } 3 \text { where } 0 \\
\text { represents no movement } \\
\text { possible, and } 3 \text { represents } \\
\text { normal performance of } \\
\text { the task }\end{array}$ & $\begin{array}{c}\text { Interpretability: As a } \\
\text { Guttman scale, level of } \\
\text { execution is effortlessly } \\
\text { comprehended and } \\
\text { contemplated. } \\
\text { Acceptability: Not proper } \\
\text { for use with proxy; } \\
\text { negligible weight for } \\
\text { patients. } \\
\text { Feasibility: A broad } \\
\text { gathering of items and } \\
\text { a particular table are } \\
\text { required. Testing must } \\
\text { be completed in a formal } \\
\text { setting }\end{array}$ & $\begin{array}{l}\text { In patients with serious } \\
\text { disabilities or close typical } \\
\text { function, the scale may } \\
\text { not be sufficiently delicate } \\
\text { to identify changes in } \\
\text { execution }\end{array}$ \\
\hline $\begin{array}{l}\text { Motor Assessment } \\
\text { Scale (MAS) })^{60}\end{array}$ & 698 & $\begin{array}{l}\text { The MAS was created } \\
\text { to obtain a substantial } \\
\text { and solid method for } \\
\text { evaluating regular } \\
\text { motor function } \\
\text { following stroke }\end{array}$ & $\begin{array}{l}\text { The MAS consists of } \\
8 \text { items relating to } 8 \\
\text { regions of motor function } \\
\text { (recumbent to side } \\
\text { lying, prostrate to sitting } \\
\text { over the edge of a bed, } \\
\text { adjusted sitting, sitting } \\
\text { to standing, walking, } \\
\text { upper-arm function, } \\
\text { hand developments and } \\
\text { propelled hand exercises). } \\
\text { Each parameter, except for } \\
\text { general tonus, is evaluated } \\
\text { utilizing a 7-point pecking } \\
\text { order of useful criteria. } \\
\text { Score extending from } 0 \\
\text { (most basic) to } 6 \text { (generally } \\
\text { complex) }\end{array}$ & $\begin{array}{l}\text { Interpretability: Scores } \\
\text { mirror a task-oriented } \\
\text { approach to assessment. } \\
\text { Acceptability: The test is } \\
\text { generally straightforward } \\
\text { and brief to manage. } \\
\text { Feasibility: The MAS is } \\
\text { freely accessible in Carr et } \\
\text { al. }{ }^{66} \text { A time of direction } \\
\text { and practice evaluation } \\
\text { is prescribed preceding } \\
\text { formal use in a clinical or } \\
\text { exploration setting }\end{array}$ & $\begin{array}{c}\text { The item "general tonus" } \\
\text { is difficult to survey in a } \\
\text { dependable manner. } \\
\text { The scoring pecking } \\
\text { order connected with the } \\
\text { propelled hand exercises } \\
\text { item }\end{array}$ \\
\hline $\begin{array}{l}\text { Six-Minute Walk Test } \\
(6 \mathrm{MWT})^{61}\end{array}$ & 48 & $\begin{array}{l}\text { The } 6 \mathrm{MWT} \text { is a } \\
\text { sub maximal test of } \\
\text { functional activity } \\
\text { limit }\end{array}$ & $\begin{array}{l}\text { The 6MWT led utilizing } \\
\text { a lobby or tracks } 100 \text { feet } \\
\text { long. } \\
\text { Patients select their own } \\
\text { power of activity and are } \\
\text { permitted to stop and rest } \\
\text { during the test, at their } \\
\text { own particular pace. } \\
\text { Performance on the } \\
\text { 6MWT is measured } \\
\text { by aggregate separation } \\
\text { strolled in feet or meters } \\
\text { within the } 6 \text { minutes. }\end{array}$ & $\begin{array}{l}\text { Interpretability: The } \\
\text { 6MWT is a broadly } \\
\text { utilized apparatus that } \\
\text { gives a quantitative } \\
\text { measure of sub-maximal } \\
\text { activity limit. It is } \\
\text { concurred that age, stature, } \\
\text { weight, and gender all } \\
\text { freely affect the 6MWT in } \\
\text { healthy adults. } \\
\text { Acceptability: The 6MWT } \\
\text { is moderately concise } \\
\text { and heavily endured } \\
\text { by patients; however, } \\
\text { its utilization may be } \\
\text { complicated by issues of } \\
\text { continuance. } \\
\text { Feasibility: The test is brief, } \\
\text { modest and easy to assess }\end{array}$ & $\begin{array}{l}\text { It is highly recommended } \\
\text { that } 6 \mathrm{MWT} \text { combined } \\
\text { with other measures for a } \\
\text { better estimate }\end{array}$ \\
\hline
\end{tabular}


Appendix 1 - Difference between the uses of outcome measures in stroke rehabilitation continued.

\begin{tabular}{|c|c|c|}
\hline $\begin{array}{l}\text { Stroke Impact Scale } \\
(\mathrm{SIS})^{62}\end{array}$ & 760 & $\begin{array}{c}\text { Surveys health status } \\
\text { after stroke }\end{array}$ \\
\hline
\end{tabular}

Medical Outcomes Study Short-Form-36 $(\mathrm{SF}-36)^{63}$

Nottingham Health Profile (NHP) ${ }^{64}$
The SF-36 is a nonspecific health survey developed to survey health status in the all inclusive community

138
A 59 item measure, 8 domains are assessed: strength ( 4 items), hand function (5 items), ADL/ IADL (10 items), mobility (9 items), communication (7 items), participation/ role function (8 items). Each item is rated on a 5-point Likert scale in terms of the difficulty the patient has experienced in completing each item. Cumulative scores are obtained for every space, scores range from 0-100.

The SF-36 consists of 8 measurements or subscales: physical functioning, role limitations-physical bodily pain, social functioning, general mental health, role limitations-emotional, vitality, and general health perceptions.

Each of the 8 summed scores is directly changed onto a scale structure 0-100 to obtain a score for every scale. Furthermore, a physical component (PCS) and mental segment score

(MCS) can be obtained

from the scale items

The NHP consists of 2 sections. Part I consists of 38 parameters grouped into 6 subsections: physical mobility (8 items), pain (8 items), sleep (5 items), social isolation ( 5 items), emotional reactions ( 9 items), and energy level (3 items). All parameters are weighted and given an aggregate score of 100 .

Part II consist of 7 items: paid livelihood, employment around the house, social life, individual connections, and sexual coexistence.

These parameters are not weighted. A score out of a total of 7 is obtained by including the quantity of positive reactions. Higher scores correlate to poorer

\author{
SIS assessment including \\ ADL; cognition; \\ communication; \\ depression; functional \\ mobility; gait; general \\ health; life participation; \\ quality of life; social \\ relationships; social \\ support; upper extremity \\ function
}

Interpretability: Utilization of the scale scores and synopsis part scores represents lost data and reduction in potential clinical interpretability. Acceptability: Fruition time is approximately 10 minutes for either the self-finished or interview managed questionnaires. Feasibility: It has been used as a mail survey with reasonably high completion rates reported

Interpretability: The NHP has been generally utilized in many countries. A

complete client's manual is accessible, as are populace standards.

Acceptability: The NHP

is short and basic form

and requires little time to complete.

Feasibility: The test can

be managed as either a self-report or verbal postal overview
Higher rates of missing information have been accounted for among older patients when utilizing the self-finished type of organization.

The SF-36 does not fit the era of a general synopsis score.

The level of test-retest unwavering quality reported in the stroke population demonstrates that the SF-36 may not

be sufficient for serial correlations of individual patients

The NHP to some degree is a constrained measure. The NHP is not suited for use in the all inclusive community wellbeing status. 
Appendix 1 - Difference between the uses of outcome measures in stroke rehabilitation continued.

\begin{tabular}{|c|c|c|c|c|c|}
\hline $\begin{array}{l}\text { Reintegration to } \\
\text { Normal Living Index } \\
\left(\text { RNLI) }{ }^{65}\right.\end{array}$ & 340 & $\begin{array}{l}\text { The RNLI was } \\
\text { created as a short } \\
\text { and straightforward } \\
\text { approach to evaluate, } \\
\text { quantitatively, the } \\
\text { extent to which } \\
\text { people who had } \\
\text { encountered traumatic } \\
\text { or debilitating sickness } \\
\text { achieve reintegration }\end{array}$ & $\begin{array}{l}\text { In the RNLI, } 11 \\
\text { decisive explanations } \\
\text { were produced. Each of } \\
\text { these announcements } \\
\text { is appraised by the } \\
\text { respondent on a } 10 \mathrm{~cm} \\
\text { visual analogue scale } \\
\text { (VAS): does not portray } \\
\text { my circumstance ( } 1 \text { or } \\
\text { negligible reintegration) } \\
\text { and completely depicts my } \\
\text { circumstance (10 or most } \\
\text { extreme reintegration). } \\
\text { Individual item scores } \\
\text { are summed to obtain } \\
\text { an aggregate score out of } \\
110 \text {, which focuses on } \\
\text { the relative changes over } \\
\text { time to obtain a score out } \\
\text { of } 100\end{array}$ & $\begin{array}{l}\text { Interpretability: There } \\
\text { are no generally } \\
\text { accepted standards for } \\
\text { understanding. } \\
\text { Acceptability: A short and } \\
\text { straightforward assessment } \\
\text { of the RNLI represents } \\
\text { negligible patient weight. } \\
\text { Feasibility: The RNLI is } \\
\text { accessible for free. It can } \\
\text { be utilized to evaluate } \\
\text { longitudinal studies }\end{array}$ & $\begin{array}{l}\text { The perfect composition } \\
\text { of the subscales is } \\
\text { questionable. } \\
\text { Reliability and legitimacy } \\
\text { have not been significantly } \\
\text { studied within the stroke } \\
\text { population }\end{array}$ \\
\hline $\begin{array}{l}\text { EuroQoL Quality of } \\
\text { Life Scale (EQ5D) }\end{array}$ & 3144 & $\begin{array}{l}\text { The EQ5D is a non- } \\
\text { specific recorded } \\
\text { instrument, created by } \\
\text { a multi-nation, multi- } \\
\text { disciplinary group, } \\
\text { used to depict well- } \\
\text { being and esteem. }\end{array}$ & $\begin{array}{l}\text { The EQ5D is a self- } \\
\text { reported survey, } \\
\text { consisting of } 2 \text { sections. } \\
\text { Part I consists of } 5 \\
\text { measurements: mobility, } \\
\text { self-care, usual activities, } \\
\text { pain/discomfort and } \\
\text { anxiety/depression). } \\
\text { Each measurement } \\
\text { is represented by } 3 \\
\text { articulations comparing } \\
\text { to } 3 \text { levels: item-1 (some } \\
\text { problems), } 2 \text { (moderate } \\
\text { problems), and } 3 \text { (extreme } \\
\text { problems). } \\
\text { Part II consists of a VAS } \\
\text { in which respondents rate } \\
\text { their present condition of } \\
\text { wellbeing from } 0 \text { (worst } \\
\text { imaginable) to } 100 \text { (best } \\
\text { possible) }\end{array}$ & $\begin{array}{l}\text { Interpretability: EQ5D } \\
\text { utilizes population base } \\
\text { utility weights to obtain } \\
\text { a standard arrangement } \\
\text { of utility qualities for the } \\
\text { 5-digit wellbeing state } \\
\text { from the 5-domain index. } \\
\text { Acceptability: Short and } \\
\text { straightforward, reports of } \\
\text { missing information are } \\
\text { blended. } \\
\text { Feasibility: It is a self- } \\
\text { reported questionnaire } \\
\text { that may be regulated as a } \\
\text { postal or phone survey or } \\
\text { in a face-to-face interview }\end{array}$ & $\begin{array}{l}\text { Not suitable for use } \\
\text { in serial evaluations of } \\
\text { individual patients. } \\
\text { Reliability was lower } \\
\text { when the post- } \\
\text { stroke intermediary } \\
\text { respondent completed } \\
\text { the questionnaire for } \\
\text { understanding on the } \\
\text { patient's behalf }\end{array}$ \\
\hline
\end{tabular}

